\title{
STEROIDAL VERSUS NON-STEROIDAL EYE DROPS IN PREVENTION OF CYSTOID MACULAR EDEMA AFTER CATARACT EXTRACTION IN DIABETIC PATIENTS
}

By

\author{
Abdullah E. Abd El-Gawad, Mohamed Mohamed-Aly Ibrahim and Amr \\ Ahmed A. El-Ganainy \\ Department of Ophthalmology, Faculty of Medicine, Al Azhar University \\ *Corresponding to: Amr Ahmed AbdelKarim El Ganainy
}

E-Mail: amrganainy7@gmail.com , Mobile: Tel: (+20) 1002256626

\begin{abstract}
Background: Cystoid macular edema (CME) is addressed as one of the most important complication responsible for suboptimal visual acuity outcome after cataract surgery.

Objective: Comparison between topical steroids versus NSAIDs regarding ability to reduce CME after uneventful cataract surgery of foldable intraocular lens (IOL) implantation in diabetic patients.

Patients and methods: In this study, 30 patients underwent phacoemulsification surgery with posterior chamber foldable intraocular lens implantation in Ophthalmology Department, Al-Azhar University Hospital between December 2017 and November 2018. Patients were randomly categorized into 2 groups. Group 1: Nepafenac eye drops (0.1\%) 3 times daily for one month, Group 2: Prednisolone eye drops (1\%) 5 times daily for one month.

Results: At the end of the follow up, foveal thickness changes in optical coherence tomography (OCT) were found to be slightly less in the no steroidal anti-inflammatory eye drops (NSAIDs) group than in the steroidal group with no significant change in the final visual outcome between the two groups.

Conclusion: There was no significant statistical difference between NSAIDs drops and steroids drops in prevention of development of pseudophakic macular edema post cataract surgery.
\end{abstract}

Keywords: CME, NSAIDs, IOL, OCT.

\section{INTRODUCTION}

Cystoid macular edema has been identified for the first time 40 years ago. It has been addressed as the most common cause of suboptimal visual outcome after cataract extraction surgery even with the advancement of new techniques of phacoemulsification (Vukicevic et al., 2012).
Although the occurrence rate of cystoid macular edema after phaco surgery is thought to be less than $2 \%$ in normal , non-complicated cataract surgery (Alnagdyet al., 2018), the incidence increase to up to $20 \%$ with the occurrence of surgery complications like posterior capsular rupture, subsequent vitreous prolapse or iatrogenic iris injury (Subramanian et al., 2009). 
The presence of diabetes mellitus makes patients more liable to the incidence of post cataract pseudophakic macular edema than normal individuals according to many studies even with no presence of preoperative macular edema or diabetic changes in the retina (Kelkaret al., 2018).

The choice of which anti-inflammatory agents to use for combating the inflammatory cascade that co-exist with cataract surgery is very important for achievement of the desired outcome regarding final vision (Hoffman et al., 2016). This includes either corticosteroids drugs group or the NSAIDs group which is the core of our study here to assess the efficacy of the two groups in controlling postoperative macular edema using the accurate measurement of central foveal thickness with the optical coherence tomography device preoperatively and postoperatively taking into consideration the peak incidence time of CME at the time of 4 to 6 weeks after the surgery ( $\mathrm{Lim}$ et al., 2016).

The present work aimed to compare the efficacy of steroidal and no steroidal anti-inflammatory eye drops in prevention of CME after cataract extraction surgery in diabetic patients.

\section{PATIENTS AND METHODS}

In this study, 30 patients underwent phacoemulsification surgery with posterior chamber foldable intraocular lens implantation in Ophthalmology Department, Al-Azhar University Hospital (From December 2017 to November 2018).

\section{Inclusion criteria:}

1. Patients with nuclear cataract grade 1 or 2

2. Diabetic patients with mild to moderate non-proliferative diabetic retinopathy without macular edema

3. Uneventful cataract surgery

\section{Exclusion criteria:}

1. Patients with history of uveitis

2. Patients receiving anti-glaucoma treatment

3. Patients with history of vasculitis like systemic lupus erythematosus, multiple sclerosis, polyarteritisnodosa, Behcet'sdisease.

\section{Ethical approval and written informed consent:}

The study was approved by the medical ethics committee of Al-Azhar Faculty of Medicine. Written informed consents were obtained from all participants included in the study after the nature and possible consequences of the procedure have been explained.

\section{The patients were randomly assigned into two groups:}

Group 1 received

Prednisoloneacetateeye drops (1\%) 5 times daily for one month.

Group 2 received Nepafenac eye drops $(0.1 \%) 3$ times daily for one month.

\section{Pre-operative Evaluation:}

1. Medical history about diabetes mellitus, hypertension, coronary artery diseases, collagen vascular diseases like rheumatoid arthritis, systemic lupus erythematosus, scleroderma and any anticoagulant therapy or drug allergy. 


\section{STEROIDAL VERSUS NON-STEROIDAL EYE DROPS IN PREVENTION... 553}

2. Evaluation of the best corrected visual acuity, intraocular pressure, past refractive surgery and possibility of any degree of amblyopia.

3. Slit lamp biomicroscopy examination to evaluate different ocular structures.

4. Biometry was done for IOL calculation.

5. OCT of the macula to determine the baseline central foveal thickness.

Phacoemulsification was followed by foldable intraocular lens implantation in the capsular bag.

\section{Postoperative Follow Up:}

Patients were examined at 1 st day, 1 st week, 2nd week, 4th week and 3 months after surgery.

\section{With evaluation of the following:}

1. Intraocular pressure at 1 st week and at 1 month.

2. Best corrected visual acuity at 1 week, 1 month and 3 months.

3. Slit lamp examination of inflammatory signs including conjunctival hyperemia, ocular pain and anterior chamber cells and flare.

4. Central foveal thickness at 1 month and 3 months measurement by OPTOVUE OCT system.

\section{Statistical analysis:}

Tables containing collected data were analyzed using Statistical Package for the Social Sciences (SPSS) version 22 (SPSS, Inc, Chicago, Illinois, USA). Data were expressed as follows:

a. Descriptive statistics: Quantitative data were presented in the form of mean $\left({ }^{-} \mathrm{X}\right)$, standard deviation (SD), range, and qualitative data were presented in the form numbers and percentages.

b. Analytical statistics: For possible association between studied factors and the targeted disease. The used tests of significance included:

Chi-square test ( $\chi 2)$ : Studying the association between two qualitative variables.

* Student t-test: for comparison between two groups having quantitative variables.

* Mann-Whitney test (nonparametric test) is a test of significance used for comparison between two groups not normally distributed having quantitative variables.

$\mathrm{P}$ value of $<0.05$ was considered statistically significant. 


\section{RESULTS}

The mean age of the studied groups was 67.5 years, ranged from 57 - 77years Table (1).

Table (1): Mean age of studied groups.

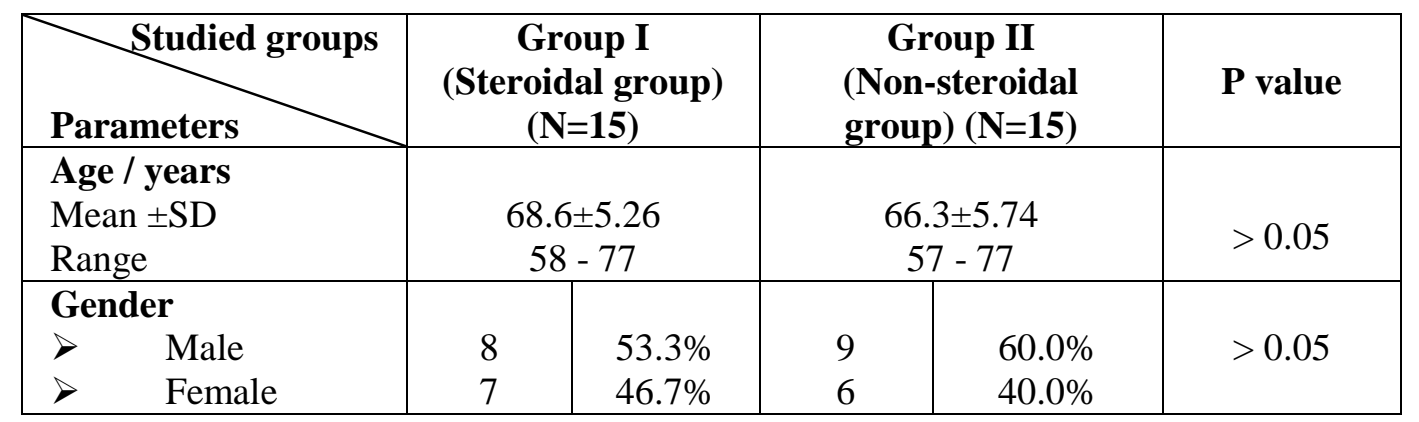

There was no significant difference between studied groups regarding their best corrected visual acuity at 1 week ( $\mathrm{p}$

value $=0.794), 1$ month $(\mathrm{p}$ value $=0.232)$ or 3 months of opeartion $(\mathrm{p}$ value $=0.803$ ) Table (2).

Table (2): BCVA at 1 week, 1 month and 3 months of operations.

\begin{tabular}{|l|c|c|c|}
\hline \multicolumn{1}{|c|}{ Studied groups } & $\begin{array}{c}\text { Group I } \\
\text { (Steroid group) } \\
\text { Parameters }\end{array}$ & $\begin{array}{c}\text { Group II } \\
\text { (Non-steroidal } \\
\text { group) (N=15) }\end{array}$ & P value \\
\hline At 1 week & $0.78 \pm 0.20$ & $0.79 \pm 0.12$ & $>0.05$ \\
Mean \pm SD & $0.33-1.0$ & $0.67-1.0$ & \\
Range & $0.79 \pm 0.16$ & $0.85 \pm 0.10$ & $>0.05$ \\
At 1 month & $0.50-1.0$ & $0.67-1.0$ & \\
Mean \pm SD & & & \\
Range & $0.85 \pm 0.15$ & $0.87 \pm 0.17$ & $>0.05$ \\
\hline At 3 months & $0.50-1.0$ & $0.40-1.0$ & \\
Mean \pm SD & \multicolumn{2}{|l}{} \\
Range & \multicolumn{2}{|l}{} \\
\hline
\end{tabular}

There was no significant difference $=0.896)$ or 1 month of operation $(\mathrm{P}$ value between studied groups regarding their intraocular pressure at 1 week $(\mathrm{P}$ value 
There was no significant difference in the preoperative central foveal thickness $(\mathrm{CFT})(\mathrm{P}$ value $=0.015)$. There was also no significant difference in the CFT at 1 month $(\mathrm{P}$ value $=0.332)$ or 3 months of operation $(\mathrm{P}$ value $=0.105)$. The mean change in the CFT was non-significant at 1 month $(\mathrm{P}$ value $=0.0191)$ and 3 months of operation $(\mathrm{P}$ value $=0.902$-Table 4$)$.

Table (4): Preoperative CFT, 1 month CFT, 3 months CFT and the change in CFT at 1 and 3 months.

\begin{tabular}{|c|c|c|c|}
\hline Sarameters & $\begin{array}{c}\text { Group I } \\
\text { (Steroidal group) } \\
(\mathrm{N}=15) \\
\end{array}$ & $\begin{array}{c}\text { Group II } \\
\text { (Non-steroidal } \\
\text { group) }(\mathrm{N}=15) \\
\end{array}$ & $P$ value \\
\hline $\begin{array}{l}\text { Preoperative CFT } \\
\text { Mean } \pm \text { SD } \\
\text { Range }\end{array}$ & $\begin{array}{c}239.8 \pm 18.6 \\
194-275\end{array}$ & $\begin{array}{c}257.8 \pm 19.3 \\
227-290\end{array}$ & $>0.05$ \\
\hline $\begin{array}{l}\text { CFT at } 1 \text { month } \\
\text { Mean } \pm S D \\
\text { Range }\end{array}$ & $\begin{array}{c}259.6 \pm 23.4 \\
232-323\end{array}$ & $\begin{array}{c}266.8 \pm 16.2 \\
239-299\end{array}$ & $>0.05$ \\
\hline $\begin{array}{l}\text { CFT at } 3 \text { months } \\
\text { Mean } \pm S D \\
\text { Range }\end{array}$ & $\begin{array}{c}254.0 \pm 28.2 \\
229-337 \\
\end{array}$ & $\begin{array}{c}272.6 \pm 32.5 \\
234-358 \\
\end{array}$ & $>0.05$ \\
\hline $\begin{array}{l}\text { CFT change at } 1 \\
\text { month } \\
\text { Mean } \pm \text { SD } \\
\text { Range }\end{array}$ & $\begin{array}{c}19.8 \pm 21.3 \\
-5-62\end{array}$ & $\begin{array}{l}9 \pm 8.63 \\
-9-28 \\
\end{array}$ & $>0.05$ \\
\hline $\begin{array}{l}\text { CFT change at } 3 \\
\text { months } \\
\text { Mean } \pm \text { SD } \\
\text { Range }\end{array}$ & $\begin{array}{c}14.2 \pm 24.3 \\
-5-76\end{array}$ & $\begin{array}{c}14.7 \pm 25.5 \\
-12-88\end{array}$ & $>0.05$ \\
\hline
\end{tabular}

OCT of patient in Fig. (1) shows preopertive CFT was 259, 274 at 1 month

and 257 at 3 months of operation and the BCVA after 3 months was $6 / 6$.

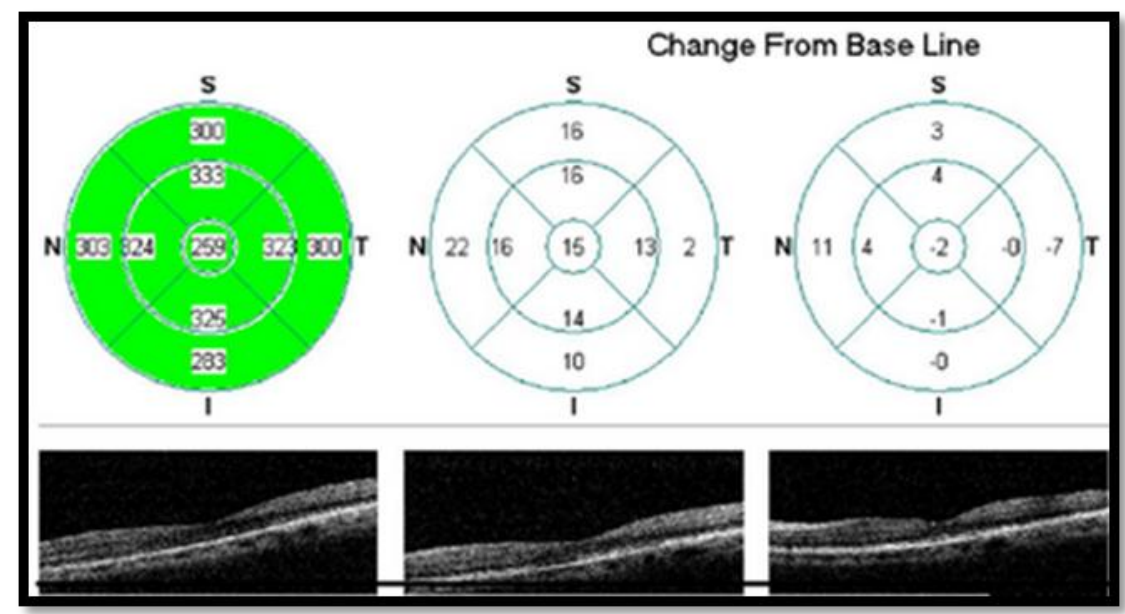

Fig. (1): OCT of patient of the steroidal group preoperatively and at 1 month and 3 months of operation.

OCT of patient in Fig. (2) shows preopertive CFT was 246, 260 at 1 month and 259 at 3 months of operation and the BCVA after 3 months was 6/9. 


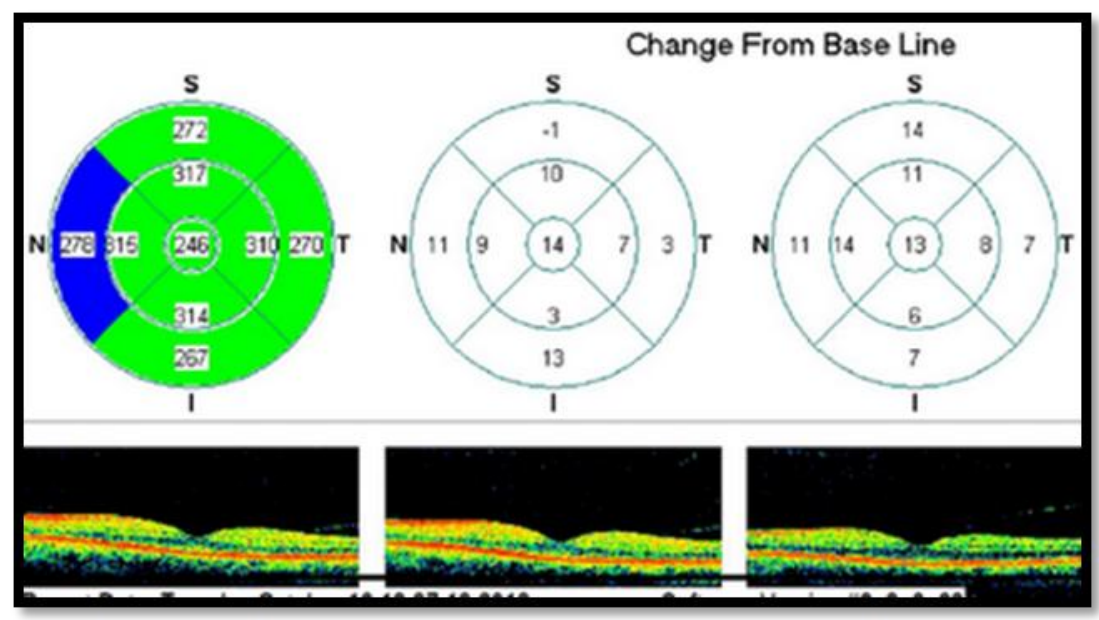

Fig. (2): OCT of patient of the steroidal group preoperatively and at 1 month and 3 months of operation.

OCT of patient in Fig. (3) shows preopertive CFT was 228, 254 at 1 month BCVA after 3 months was $6 / 12$.
Fig. (3): OCT of patient of the steroidal group preoperatively and at 1month and 3 and 289 at 3 months of operation and the

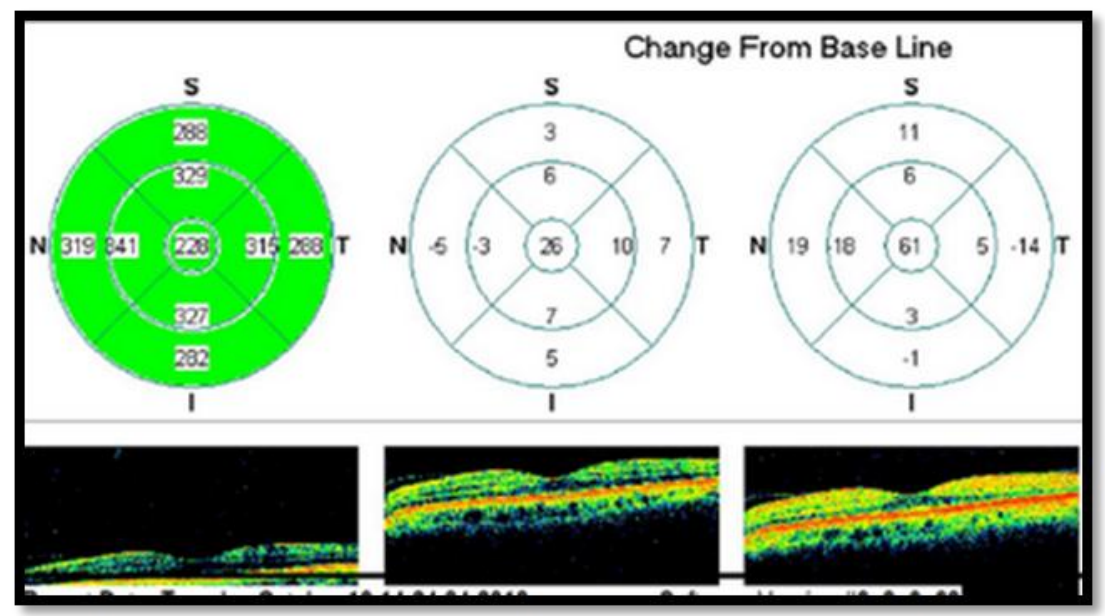

months of operation.

OCT of patient in Fig. (4) shows month and 240 at 3 months of operation preopertive CFT was 255, and 274 at 1 and the BCVA after 3 months was $6 / 6$.

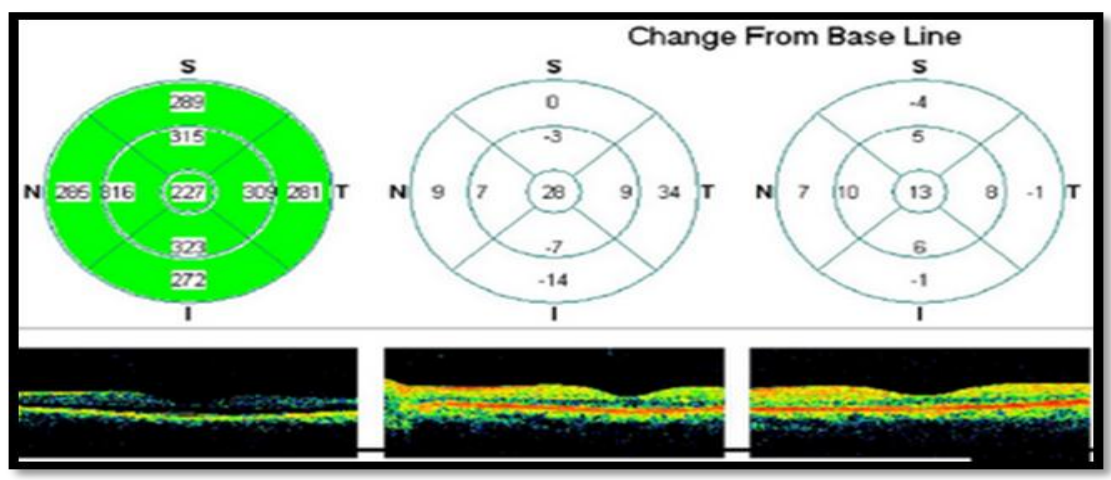

Fig. (4): OCT of patient of the non-steroidal group preoperatively and at 1month and 3 months of operation. 
OCT of patient in Fig. (5) shows preopertive CFT was 252, 259 at 1 month and 301 at 3 months of operation and the BCVA after 3 months was 6/12.

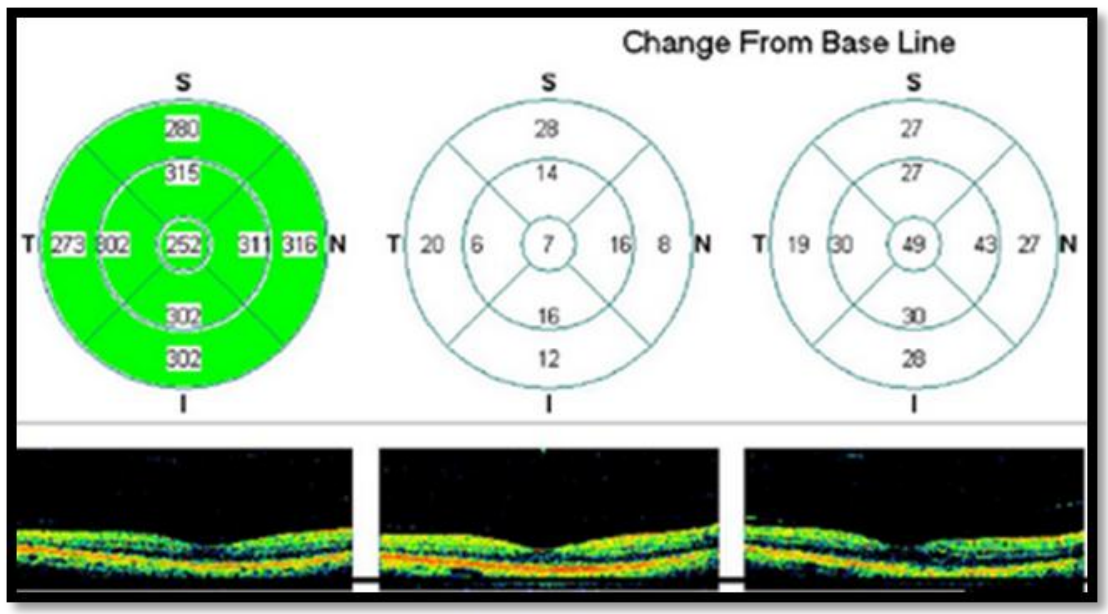

Fig. (5): OCT of patient of the non-steroidal group preoperatively and at 1 month and 3 months of operation.

OCT of patient in Fig. (6) shows preopertive CFT was 229, 239 at 1 month

and 237 at 3 months of operation and the BCVA after 3 months was 6/6.

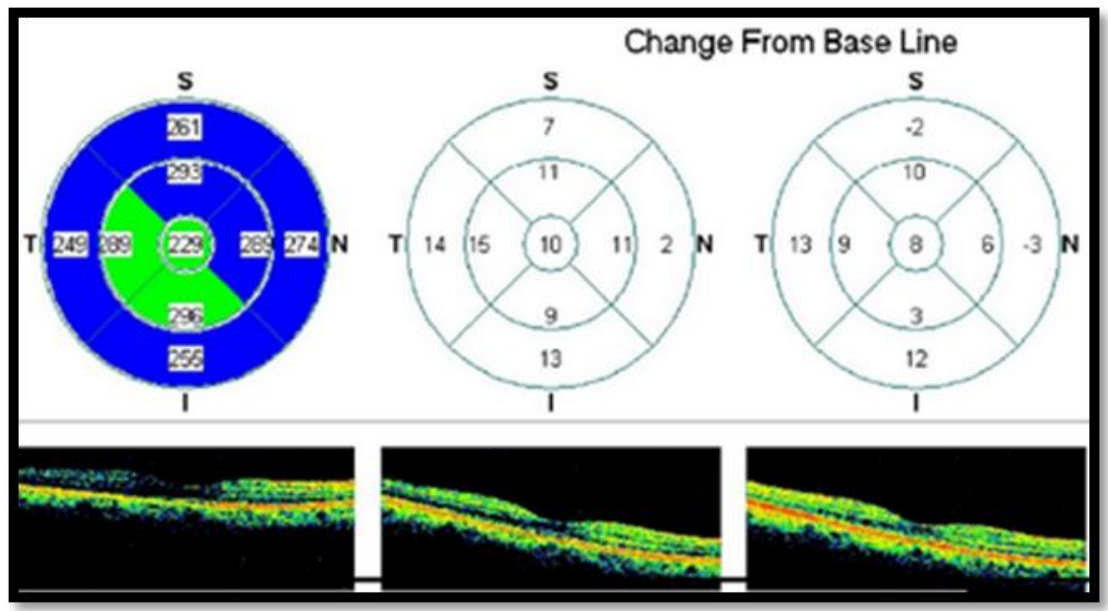

Fig. (6): OCT of patient of the non-steroidal group preoperatively and at 1 month and 3 months of operation.

\section{DISCUSSION}

The mean best corrected visual acuity (BCVA) was slightly better in the nonsteroidal group postoperatively after 1 month and 3 months follow ups (peak time for CME incidence reported), but the difference was non-significant. The incidence of central foveal thickness changes was less evident in the NSAIDs group than in the steroids group.

The mean change in central foveal thickness after one month in the steroid group was $(-5$ to -62$)$, while in the no steroidal group it was $(-9$ to -28$)$ with a mean difference which was nonsignificant. After three months, the mean change in central foveal thickness in the 
steroid group was $(-5-76)$, while in the no steroidal group it was $(-12-88)$ with a mean difference which was also nonsignificant.

The NSAIDs are considered safe in glaucoma patients. However, other side effects should be cautiously observed like conjunctival hyperemia, burning sensation, stinging and even up to toxic keratitis and corneal melting (Smith and Goldmann, 2012).

Different factors can affect the results for the prevalence percentage of pseudophakic macular edema including the technique of the performed surgery, the evaluation methods and devices used, the times of follow up visits and incidence of complications (Grzybowski et al., 2016).

In this study, we did not exclude patients with ocular surface diseases or seasonal allergy like vernal keratoconjunctivitis or atopic keratoconjunctivitis. Inflammatory mediators were always present in those patients, and may be responsible for different post-surgical inflammations. So, this should be taken into consideration in further studies.

In our study, we used drugs available commercially which includes a preservative chemical which is well known to affect the efficacy of the drug. Other studies might have used preservative-free dugs postoperatively and this could affect the results (Kim et al., 2013).

The studies about the intracameral NSAIDs used before surgery and at the day of the surgery showed that the levels of NSAIDs in the aqueous humor were minimum. No studies were found about intracameral injection of NSAIDs to reduce miosis or prevent inflammatory mediators release during surgery (Jha et al., 2018).

The prophylactic use of NSAIDs for protection against post cataract Pseudophakic macular edema was addressed by Lim et al. (2016) and it was found that the combined use of NSAIDs and steroids eye drops gives better control on the macular thickness changes than the sole use of each of them.

Kessel et al. (2014) compared the efficacy of different types of NSAIDs and steroids eye drops in prohibition of post cataract surgery macular edema, the incidence rate in the steroids group was higher $(25.3 \%)$ than that in the nonsteroidal group $(3.8 \%)$ with nearly no difference in the final visual outcome. They recommended that the use of NSAIDs is even superior.

A multicenter study done by Denniston et al. (2017) in patients with diabetes mellitus with no history of DME underwent cataract extraction surgery. The study showed a link between the incidence of post-surgery pseudophakic macular edema and preoperative diabetic retinopathy grade. Incidence was $1 \%$ in patients with no diabetic retinopathy changes, $5.4 \%$ in patients with mild nonproliferative diabetic retinopathy (NPDR) changes, $10 \%$ in patients with moderate changes, $13.1 \%$ in patients with severe NPDR changes, and $4.9 \%$ in proliferative diabetic retinopathy patients. This study had the advantage of scanning a large number of cases with the accurate classification of the diabetic retinopathy condition of the eye which allowed them 


\section{STEROIDAL VERSUS NON-STEROIDAL EYE DROPS IN PREVENTION... 559}

to address the link between diabetic retinopathy stage and incidence of pseudophakic macular edema.

Duong et al. (2014) had compared two types of anti-inflammatory drugs used post cataract surgery in diabetic patients. They did not comment on the rate of occurrence of pseudophakic macular edema. The change in the central foveal thickness was approximately the same in both groups. However, there was a significant higher improvement in the final visual acuity in the NSAIDs group at the 6 weeks follow up visit.

The ESCRS PREMED study had compared combined use of dexamethasone $(0.1 \%)$ and bromfenac $(0.09 \%)$ versus the single use of each one of them in the no diabetic patients. The combined group has shown less chance for development of pseudophakic macular edema than each of the single drug used alone. However, it was not statistically different regarding the final BCVA. So they referred that individual patients will get the best benefit from the optimum prohibition of significant PME (Wielders et al., 2018).

Our study was limited by small number of patients and the inability to follow the patients for a longer time to evaluate the long term control on the central foveal thickness changes by these drugs. But we tried to focus on the time with the higher probability to develop post-surgery PME. The visual functions was only assessed by the visual acuity measurement which may underestimate the effect of CME on other parameters of visual functions as contrast sensitivity which is more affected by CME.
The addition of new methods to evaluate the vascular integrity like the OCT angiography may give us more details during the follow up of the patients especially the ones who already develops CME after phacoemulsification surgery.

\section{CONCLUSION}

The use of NSAIDs after cataract extraction surgery was almost equivalent in efficacy and prevention of complications to the use of steroids eye drops with the addition to the safety of NSAIDs in glaucoma patients and lesser side effects than those of the steroids eye drops. There was no significant statistical difference between NSAIDs drops and steroids drops in prevention of development of pseudophakic macular edema post cataract surgery. The use of NSAIDs drops can be safer than steroids drops in certain conditions such as glaucoma patients.

\section{REFERENCES}

1. Alnagdy AA, Abouelkheir HY, El-Khouly SE and Tarshouby SM. (2018): Impact of topical nonsteroidal anti-inflammatory drugs in prevention of macular edema following cataract surgery in diabetic patients. Int $\mathrm{J}$ Ophthalmol., 18; 11(4):616-622.

2. Denniston AK, Chakravarthy U, Zhu H, Lee AY, Crabb DP, Tufail A, Bailey C, Akerele T, Al-Husainy S, Brand C, Downey L, Fitt A, Khan R, Kumar V, Lobo A, Mahmood S, Mandal K, Mckibbin M, Menon G, Natha S, Ong JM, Tsaloumas MD, Varma A, Wilkinson E, Johnston RL, Egan CA and UK DR EMR Users Group. (2017): The UK Diabetic Retinopathy Electronic Medical Record (UK DR EMR) Users Group, Report 2: real-world data for the impact of cataract surgery on diabetic macular oedema. British Journal of Ophthalmology, 101:1673-1678. 
3. Duong H-VQ, Westfield KC, Singleton IC. (2014): Treatment paradigm after uncomplicated cataract surgery: a prospective evaluation. Asia Pac J Ophthalmol (Phila), 3(4):220-225.

4. Grzybowski A, Sikorski BL, Ascaso FJ and Huerva V. (2016): Pseudophakic cystoid macular edema: update 2016. Clin Interv Aging, 9; 11:1221-1229.

5. Hoffman RS, Braga-Mele R, Donaldson K, Emerick G, Henderson B, Kahook M, Mamalis N, Miller KM, Realini T, Shorstein NH, Stiverson RK, and Wirostko B; ASCRS Cataract Clinical Committee and the American Glaucoma Society. (2016): Cataract surgery and nonsteroidalantiinflammatory drugs. J Cataract Refract Surg., 42(9): 1368-1379.

6. Jha R, Sur V, Bhattacharjee A, Ghosh T, Kumar V, Konar A and HazraS. (2018): Intracameral Use of Nepafenac: Safety and Efficacy Study. Curr Eye Res., 43(5):630-638.

7. Kelkar A, Kelkar J, Mehta $H$ and Amoaku W. (2018): Cataract surgery in diabetes mellitus: A systematic review. Indian J Ophthalmol., 66(10): 1401-1410.

8. Kessel L, Tendal B, Jørgensen KJ, Erngaard D, Flesner P, Andresen JL and Hjortdal J. (2014): Post-cataract prevention of inflammation and macular edema by steroid and nonsteroidal anti-inflammatory eye drops: a systematic review. Ophthalmology, 121(10):1915-1924.

9. Kim EJ, Kim YH, Kang SH, Lee KW and Park YJ. (2013): In vitro effects of preservative-free and preserved prostaglandin analogs on primary cultured human conjunctival fibroblast cells. Korean J Ophthalmol., 27(6):446-453.

10. Lim BX, Lim CH, Lim DK, Evans JR, Bunce $C$ and WormaldR. (2016): Prophylactic non-steroidal anti-inflammatory drugs for the prevention of macular oedema after cataract surgery. Cochrane Database Syst Rev, 11: CD006683.

11. Smith CH and Goldman RD. (2012): Topical nonsteroidal anti-inflammatory drugs for corneal abrasions in children.Can FamPhysician., 58(7):748-749.

12. Subramanian ML, Devaiah AK and Warren KA. (2009): Incidence of postoperative cystoid macular edema by a single surgeon.Digit J Ophthalmol., 28; 15(4):37-41.

13. Vukicevic $M$, Gin $T$ and Al-Qureshi $S$. (2012): Prevalence of optical coherence tomography-diagnosed postoperative cystoid macular oedema in patients following uncomplicated phaco-emulsification cataract surgery. Clin Exp Ophthalmol., 40(3):282287.

14. Wielders LHP, Schouten JSAG, Winkens B, van den Biggelaar FJHM, Veldhuizen CA, Findl O, Murta JCN, Goslings WRO, Tassignon MJ, Joosse MV, Henry YP, Rulo AHF, Güell JL, Amon M, Kohnen T and Nuijts RMMA; ESCRS PREMED Study Group. (2018): European multicenter trial of the prevention of cystoid macular edema after cataract surgery in nondiabetics: ESCRS PREMED study report 1 . J Cataract Refract Surg : 44: 429-439. 
قطر ات العين الاستيرويدية و الغير استيرويدية لمنع إلتهابات

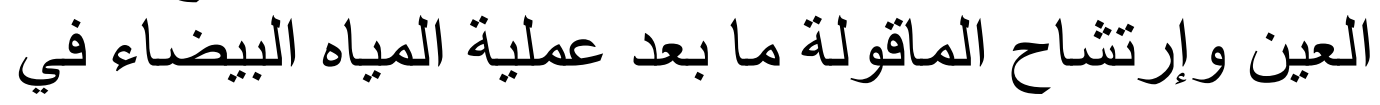
مرضى السكري

عبدالله الحسيني عبدالجواد، محمد محمد علي ابراهير، عمرو أحمد الجنايني قسم طب و جراحة العيون، كلية الطب، جامعة الأزهر

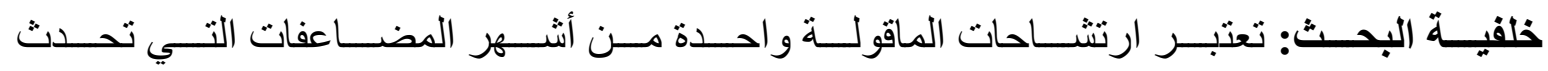

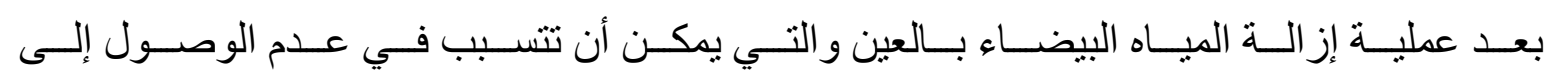
حدة الإبصار المرجوة بعد اجراء العملية.

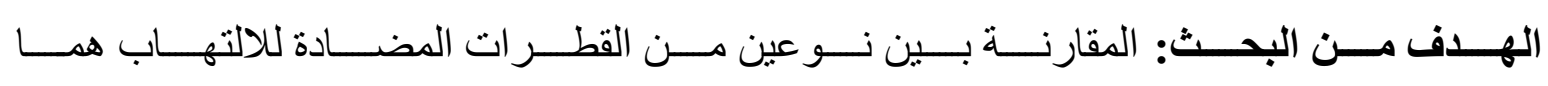

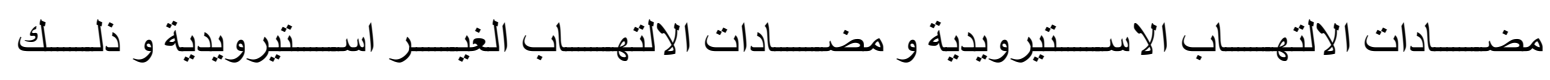

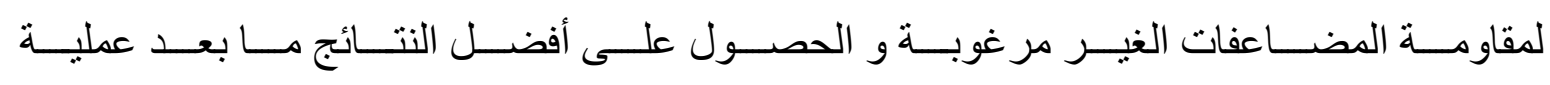
إزالة المياه البيضاء في مرضى السكري.

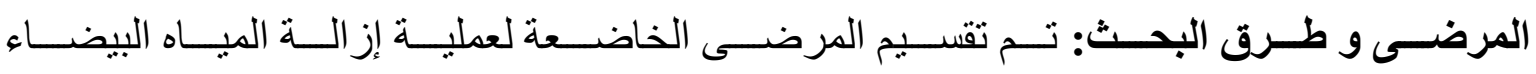

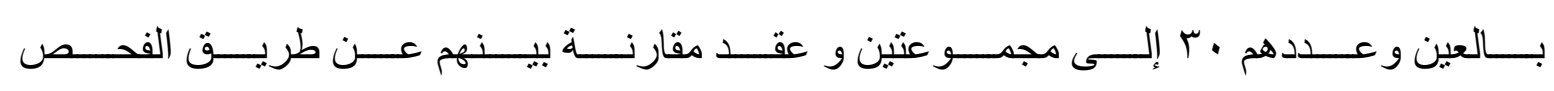

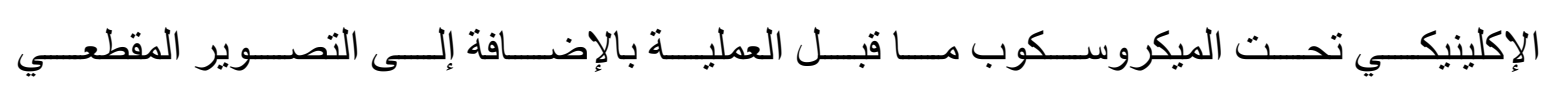

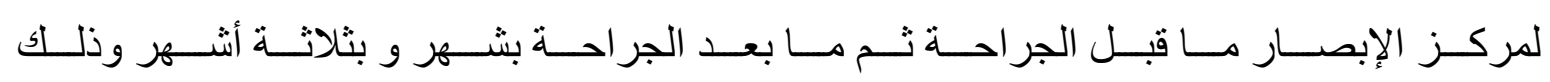
بقسم طب و جراحة العيون بجامعة الأزهر.

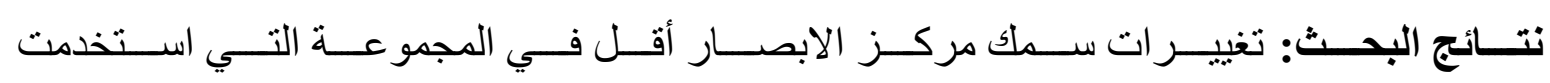

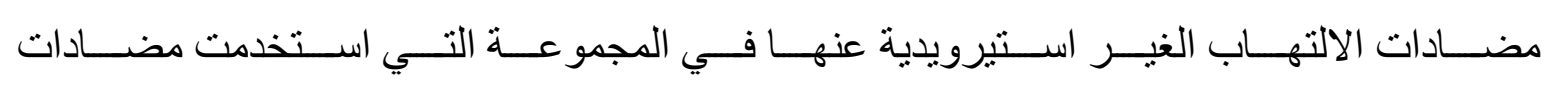

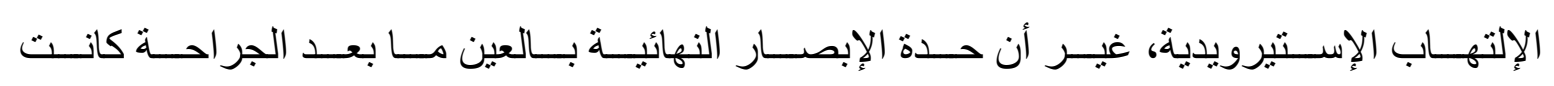

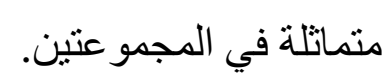

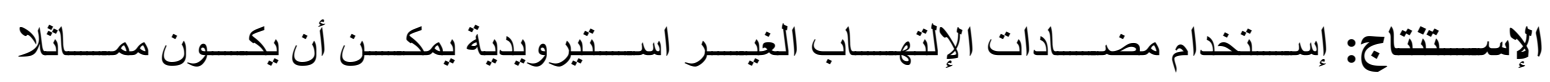

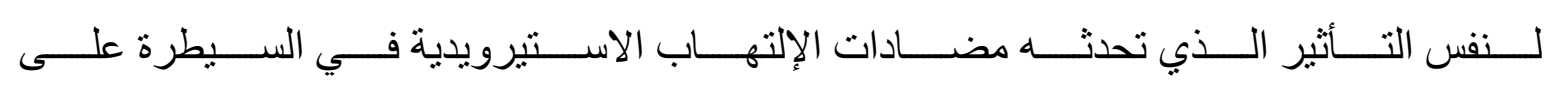

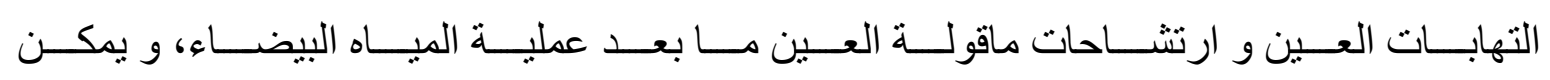


ABDULLAH E. ABD EL-GAWAD et al.,

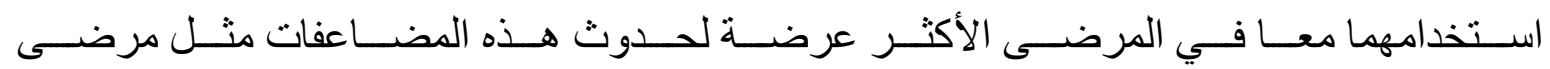
السكري. 